\title{
Sediment-water column fluxes of carbon, oxygen and nutrients in Bedford Basin, Nova Scotia, inferred from ${ }^{224}$ Ra measurements
}

\author{
W. J. Burt ${ }^{1}$, H. Thomas ${ }^{1}$, K. Fennel ${ }^{1}$, and E. Horne ${ }^{2}$ \\ ${ }^{1}$ Dalhousie University, Department of Oceanography, Halifax, NS, Canada \\ ${ }^{2}$ Bedford Institute of Oceanography, Fisheries \& Oceans Canada, Dartmouth, NS, Canada \\ Correspondence to: W. J. Burt (willburt@dal.ca)
}

Received: 15 June 2012 - Published in Biogeosciences Discuss.: 24 July 2012

Revised: 28 November 2012 - Accepted: 5 December 2012 - Published: 8 January 2013

\begin{abstract}
Exchanges between sediment pore waters and the overlying water column play a significant role in the chemical budgets of many important chemical constituents. Direct quantification of such benthic fluxes requires explicit knowledge of the sediment properties and biogeochemistry. Alternatively, changes in water-column properties near the sediment-water interface can be exploited to gain insight into the sediment biogeochemistry and benthic fluxes. Here, we apply a 1-D diffusive mixing model to near-bottom watercolumn profiles of ${ }^{224} \mathrm{Ra}$ activity in order to yield vertical eddy diffusivities $\left(K_{Z}\right)$, based upon which we assess the diffusive exchange of dissolved inorganic carbon (DIC), nutrients and oxygen $\left(\mathrm{O}_{2}\right)$, across the sediment-water interface in a coastal inlet, Bedford Basin, Nova Scotia, Canada. Numerical model results are consistent with the assumptions regarding a constant, single benthic source of ${ }^{224} \mathrm{Ra}$, the lack of mixing by advective processes, and a predominantly benthic source and sink of DIC and $\mathrm{O}_{2}$, respectively, with minimal water-column respiration in the deep waters of Bedford Basin. Near-bottom observations of DIC, $\mathrm{O}_{2}$ and nutrients provide flux ratios similar to Redfield values, suggesting that benthic respiration of primarily marine organic matter is the dominant driver. Furthermore, a relative deficit of nitrate in the observed flux ratios indicates that denitrification also plays a role in the oxidation of organic matter, although its occurrence was not strong enough to allow us to detect the corresponding $A_{\mathrm{T}}$ fluxes out of the sediment. Finally, comparison with other carbon sources reveal the observed benthic DIC release as a significant contributor to the Bedford Basin carbon system.
\end{abstract}

\section{Introduction}

A fraction of the particulate organic matter (POM), generated photosynthetically in the euphotic zone, settles to the sediment, where microbes utilize a variety of electron acceptors to respire this organic material, producing dissolved inorganic carbon (DIC) and nutrients. As a result, sediment pore waters become highly concentrated in many chemical constituents relative to the overlying water column (Moore et al., 2011; Charette et al., 2007), so that small volumes of released fluid can have disproportionately large affects on biogeochemical cycles and budgets (Berelson et al., 1987). Furthermore, if considering the area over which these processes can occur, from smaller basins to entire continental margins, fluxes from sediments can be a major source or sink in various coastal chemical budgets (Fennel et al., 2006). For example, in the shallow mud flats of the North Sea, anaerobic alkalinity generation within the sediments, and its subsequent release, may facilitate up to $25 \%$ of the North $\mathrm{Sea} \mathrm{CO}_{2}$ uptake (Thomas et al., 2009). Pore water fluxes in the shallow Wadden Sea have been shown to largely control the budgets of numerous important chemical constituents, including alkalinity, silica, manganese and uranium (Moore et al., 2011). Consequently, many studies have focused on quantifying the release of pore waters in coastal environments (Colbert and Hammond, 2008; Jahnke and Jahnke, 2000; Hancock et al., 2006; Simmons Jr., 1992), and modelling the biogeochemistry of chemical fluxes across the sediment-water interface (Fennel et al., 2009).

Pore waters enter the water column via a number of different physical processes, many of which occur at slow rates, making their detection and quantification difficult (Burnett 
et al., 2003). However, if we assume that fluxes across the sediment-water interface are controlled by diffusive processes, such fluxes out of the pore waters into the overlying water column can be inferred using the short-lived radioactive tracer, ${ }^{224}$ Radium $\left({ }^{224} \mathrm{Ra}\right)$, a powerful tool commonly used for estimating various types of fluxes from sediment pore waters. Due to its high affinity for sediment surfaces, ${ }^{228}$ Thorium $\left({ }^{228} \mathrm{Th}\right)$, the longer-lived parent isotope of ${ }^{224} \mathrm{Ra}$, is ever present within bottom sediments. Consequently, ${ }^{224} \mathrm{Ra}$, which has a much lower affinity for sediment surfaces, is constantly produced and becomes highly concentrated in the interstitial pore water. As this ${ }^{224} \mathrm{Ra}$ diffuses into the overlying water column, it is mixed away from its source, and its activity decreases. Utilizing the decay timescales of ${ }^{224} \mathrm{Ra}\left(t_{1 / 2}=3.66 \mathrm{~d}\right)$, diffusion rates near the seafloor can be estimated and subsequently applied to chemical gradients of other dissolved constituents.

Sediment-water column exchange of carbon and nutrients is often quantified using in situ benthic flux chambers (Berelson et al., 1987; Jahnke et al., 2000; Jahnke and Jahnke, 2000). Alternatively, benthic fluxes can be estimated by measuring pore water profiles of nutrients or metals (Emerson et al., 1984; Jahnke et al., 2005; Lettmann et al., 2012) or more recently, radium isotopes (Hancock et al., 2006; Colbert and Hammond, 2008; Moore et al., 2011) and applying models to the resulting gradients. Modelling pore water data, however, requires a thorough understanding of various sediment characteristics (i.e. composition, porosity, density), which often involve intricate lab experiments using sediment cores and can result in highly uncertain estimates, especially when dealing with permeable sediments (Huettel and Webster, 2001).

Previous studies in Bedford Basin have indirectly measured rates of organic carbon sedimentation and sediment oxygen uptake using sediment trap data (Hargrave et al., 1976; Hargrave and Taguchi, 1978). However, to the best of our knowledge, our study represents the first publication describing direct benthic flux observations in Bedford Basin. Here, a more direct observational approach is applied to measure the fluxes of ${ }^{224} \mathrm{Ra}$, DIC and dissolved oxygen $\left(\mathrm{O}_{2}\right)$ between the sediments and water column that relies on watercolumn observations. Specifically, we estimated the vertical diffusive flux of the short-lived ${ }^{224} \mathrm{Ra}$ from the seafloor into the bottom water in Bedford Basin (Halifax Harbour, NS). Then, we apply a 1-D diffusion model to near-bottom vertical profiles of ${ }^{224} \mathrm{Ra}$ to asses both the vertical eddy diffusivity in the water column $\left(K_{Z}\right)$, and the ${ }^{224}$ Ra activity at the sediment surface $\left(A_{0}\right)$. These calculated values, along with estimates of the benthic flux of ${ }^{224} \mathrm{Ra}$ per unit area of seafloor, are compared to other published values from similar studies. Near-bottom gradients of DIC and $\mathrm{O}_{2}$ are then used in conjunction with the estimates of $K_{Z}$ to quantify the diffusive release of carbon into the water column and corresponding uptake of $\mathrm{O}_{2}$ by the sediments. Further, estimates of nutrient (nitrate and phosphate) fluxes are also made using time se- ries observations of oxygen and nutrients at the bottom of the basin. Calculated flux ratios provide insight about the dominant pathways of organic matter remineralization, and a time-dependent finite difference diffusion model is used to test the assumptions regarding steady-state and the contributions of secondary sources and sinks. By relating the inferred carbon flux with estimates of both riverine DIC input and uptake by primary production, the relative contribution of the benthic DIC flux to the carbon budget in Bedford Basin is established.

\section{Methods}

\subsection{Study site}

Observations were made between October and December of 2010 at the Compass Buoy Station in Bedford Basin, Nova Scotia, Canada $\left(44^{\circ} 41^{\prime} 30^{\prime \prime} \mathrm{N}, 63^{\circ} 38^{\prime} 30^{\prime \prime} \mathrm{W}\right)$. Bedford Basin is a small enclosed bay ( $6 \mathrm{~km}$ long by $4 \mathrm{~km}$ wide) at the northwestern end of Halifax Harbour (Fig. 1). The Basin reaches water depths of over $70 \mathrm{~m}$, while the rest of Halifax Harbour is relatively shallow (Fig. 1). The only major fresh water source in the region, the Sackville River, drains into the northwestern side of Bedford Basin with an approximate annual discharge of $1.5 \times 10^{8} \mathrm{~m}^{3} \mathrm{yr}^{-1}$ (Kepkay et al., 1997). At the southeastern edge, water exits into the Narrows, eventually leading to the Halifax Outer Harbour and the Scotian Shelf.

The general circulation pattern of Halifax Harbour is described as a two-layer, estuarine-type circulation with a relatively fresh upper layer moving seaward, driven by inputs from the Sackville River and a saltier deep-water return flow (Fader and Miller, 2008). However, this circulation is at its weakest in Bedford Basin, with a mean surface outflow of $0.2 \mathrm{~cm} \mathrm{~s}^{-1}$. Also, the entrance to the Narrows is marked by a shallow sill with a depth of about $20 \mathrm{~m}$. While significant tidal currents can be observed within the Narrows, the presence of the sill largely prevents mixing below a $20-30 \mathrm{~m}$ depth in the Basin (Shan et al., 2011). As a result, and as seen in the homogenous temperature and salinity distributions (Fig. 2), the subsurface layers of Bedford Basin are a relatively stable environment, which, for the purpose of this study, allows us to apply the 1-D diffusive model described below. However, periodic storms in the spring and fall can result in deep-water ventilation events, one of which occurred in October 2010 and terminated toward the start of the sampling period (Figs. 2-4). These events can result from windinduced deep vertical mixing during periods of minimum stratification (Punshon and Moore, 2004). However, the October 2010 event is more likely to have resulted via lateral intrusion, the mechanism of which is described as a combination of strong along-shore winds and large tides, causing a build-up of coastal sea level and bringing dense water from the outer harbour over the sill and into the deep basin 

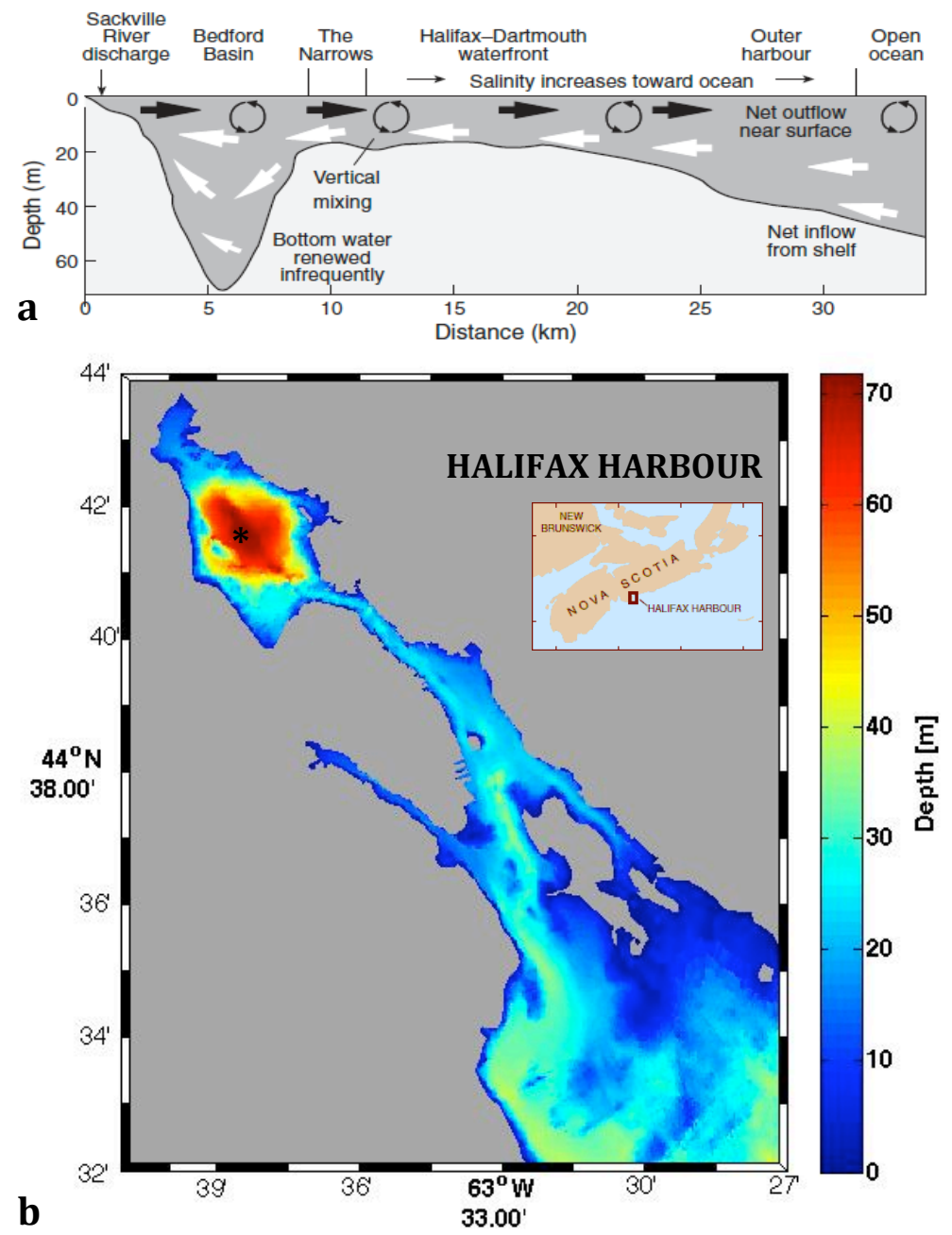

Fig. 1. (a) Schematic cross-section of Halifax Harbour (with permission from Fader and Miller, 2008). (b) Bathymetric map of Halifax Harbour, showing the Compass Buoy Site $\left(^{*}\right)$.

(Platt et al., 1972). Regardless of the specific mechanism for their occurrence, these events result in abrupt changes in the physical and chemical characteristics of the deep-water column (Fig. 2), bringing surface waters saturated with $\mathrm{O}_{2}$ into the deep basin and preventing the deep waters from reaching anoxic conditions (Fig. 3; Hargrave et al., 1976). Concurrently, deep waters, rich in DIC and nutrients, are brought to the surface, occasionally marking the onset of the spring or autumn phytoplankton bloom (Fig. 3).

The close proximity of Bedford Basin to both the Bedford Institute of Oceanography (BIO) and Dalhousie University permits convenient access for weekly measurements. The Bedford Basin Plankton Monitoring Program conducted at BIO has been carrying out weekly measurements of various water properties, including nutrients, plankton records, and CTD profiles at the Compass Buoy Site for nearly $30 \mathrm{yr}(\mathrm{Li}$ and Dickie, 2001). Also, the lack of significant horizontal or vertical advective flows in the deep waters of Bedford Basin allows for a reliable application of the assumptions neces- sary for the 1-D diffusion model utilized in this study. These assumptions follow those made by Moore (2000), and are described in more detail below.

\subsection{Analytical methods}

Samples of ${ }^{224}$ Ra were taken aboard the vessel CCGS Sigma $\mathrm{T}$, operated out of the Bedford Institute of Oceanography. In total, five vertical profiles of ${ }^{224} \mathrm{Ra}$ were sampled regularly over a six week period between October and December of 2010. Each sample requires a large volume of water (150-200 L) which was obtained at the surface $(\sim 2 \mathrm{~m})$ using a small bilge pump that was lowered over the side of the vessel, and at depth using repeated casts of $30 \mathrm{~L}$ Niskin bottles lowered to the appropriate depths. Sampling depths varied for each daily profile due to varying weather conditions, with bottom sampling depths ranging from $66-70 \mathrm{~m}$ and a vertical spacing of 6-8 $\mathrm{m}$ between samples (see Fig. 5). Once collected, sample volumes were pumped through $10 \mu \mathrm{m}$ and 

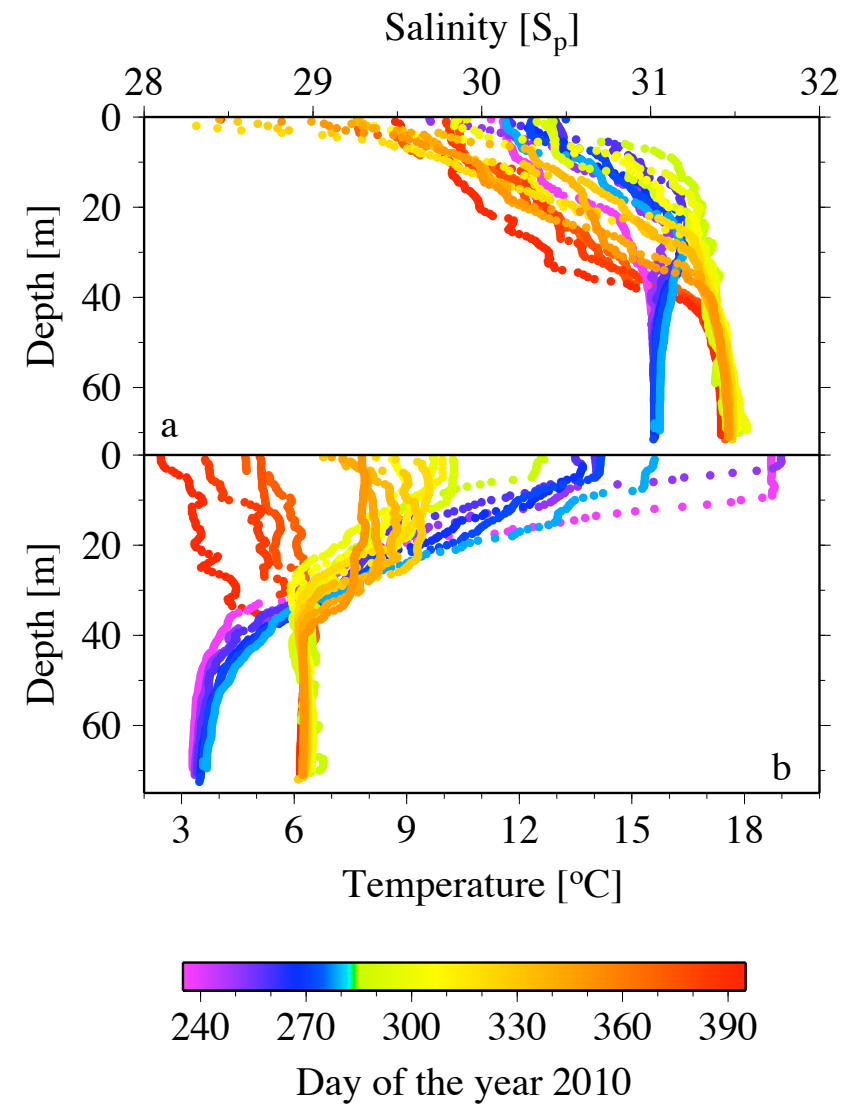

Fig. 2. Weekly vertical profiles of salinity $\left(S_{\mathrm{p}}\right)(\mathbf{a})$ and temperature (b) from August 2010 (day 237)-January 2011 (day 391). The color bar has been adjusted at day 282 ( 9 October) in order to better illustrate the abrupt changes in the deep waters around that day.

$1 \mu \mathrm{m}$ cartridge filters to remove any particles, effectively removing all sources of the parent ${ }^{228} \mathrm{Th}$ isotopes. The water was then passed slowly $\left(<1 \mathrm{~L} \mathrm{~min}^{-1}\right)$ through plastic cartridges packed with $20 \mathrm{~g}$ of pre-weighed $\mathrm{MnO}_{2}$-impregnated fiber, which quantitatively extracts the Ra isotopes (Moore, 1987). The fibers were then rinsed with deionized water and dried to a water/fiber ratio between 0.3-1.1, using compressed air to maximize the emanation of radon $(\mathrm{Rn})$ from the fibers during counting (Sun and Torgersen, 1998).

In order to analyze ${ }^{224} \mathrm{Ra}$ activities of samples, the cartridges were placed onto the $\mathrm{RaDeCC}$ coincidence counting system described by Moore and Arnold (1996). Using the electronic time windows within a photomultiplier tube (PMT), the instrument is able to identify and distinguish between the alpha particles created by the decay of ${ }^{224} \mathrm{Ra}$ as well as its respective daughter, ${ }^{220} \mathrm{Rn}$. To minimize initial decay, all samples were counted within 2 days of collection. The samples were then aged for approximately 3 weeks, allowing all excess ${ }^{224} \mathrm{Ra}$ to equilibrate with parent ${ }^{228} \mathrm{Th}$ before recounting to calculate the initial supported Ra. The uncertainty in the ${ }^{224} \mathrm{Ra}$ measurements ranges between $7-10 \%$.

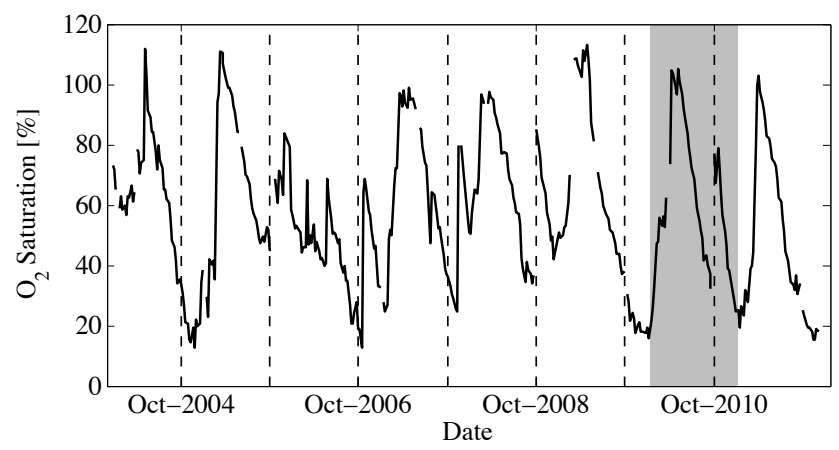

Fig. 3. Deep-water $(60 \mathrm{~m})$ oxygen saturation time series at the Compass Buoy Site in Bedford Basin. Vertical dotted lines are drawn at mid-October of each year. An abrupt increase indicates a deepwater mixing event. Two distinct events are shown to occur in 2010 (shaded box).

The majority of the Ra samples were also accompanied by bottle samples of dissolved inorganic carbon (DIC) and alkalinity $\left(A_{\mathrm{T}}\right)$. These samples were collected and poisoned with a $\mathrm{HgCl}_{2}$ solution to halt biological activity, before being stored for later analysis. Both DIC and $A_{\mathrm{T}}$ were analyzed on the VINDTA 3C (Versatile Instrument for the Determination of Titration Alkalinity by Marianda) by coulometric and potentiometric titrations respectively (see Johnson et al., 1993, for a full description of instrumental methods).

Vertical profiles of temperature, conductivity, and pressure were collected using a seabird SBE25 CTD profiler, equipped with a Beckman/YSI type dissolved oxygen sensor. Additionally, discrete bottle samples (at 1, 5, 10, $60 \mathrm{~m}$ depth) were taken using Niskin bottles and analyzed for various biological and chemical species as part of the Bedford Basin Monitoring Program, providing time series data of $\mathrm{O}_{2}$, nitrate $\left(\mathrm{NO}_{3}^{-}\right)$, phosphate $\left(\mathrm{PO}_{4}^{3-}\right)$, chlorophyll $(\mathrm{Chl} a)$ and particulate organic carbon (POC) during the sampling period. This additional sampling always took place within 1 day of radium sampling. Nitrate and phosphate were measured using a Technicon II autoanalyzer, Chl $a$ analysis was done using a fluorescence technique (Turner Design Model 10 Fluorometer) (Li and Dickie, 2001), and POC was measured on a Perkin Elmer Series II CHNS/O Analyzer 2400 (for more information, please refer to $\mathrm{Li}$ and Harrison, 2008).

\subsection{Vertical mixing coefficients derived from Radium tracers}

The method for quantifying turbulent diffusion near the sediment surface is based on the 1-D model used in conjunction with short-lived Ra isotopes by Moore (2000), and subsequently applied in various settings (Moore, 2003; Charette et al., 2007; Men et al., 2011; Moore and Oliveira, 2008). The original model quantified the diffusive flux of short-lived Ra isotopes in the horizontal direction from a point source (i.e. the coast) towards the open ocean. The model used here takes 


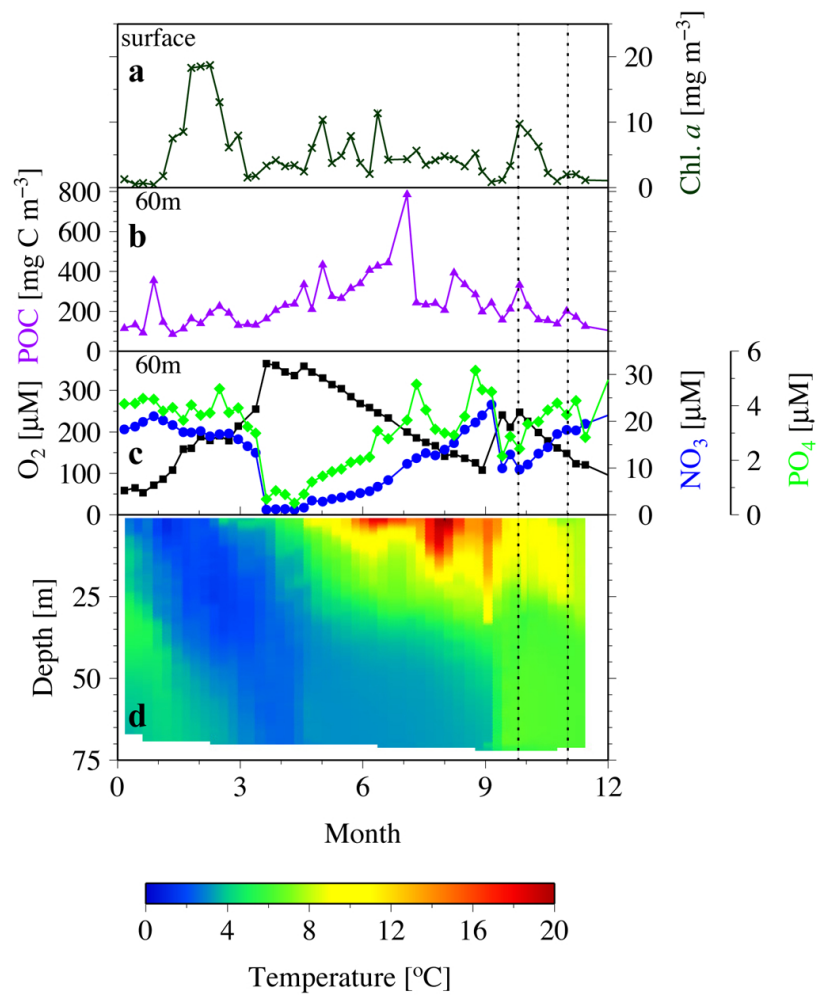

Fig. 4. Time series of surface Chl $a$ (a), deep-water particulate organic carbon (POC) (b), deep-water oxygen and nutrients (c), and temperature depth profiles (d) in Bedford Basin during 2010. Black dashed lines indicate the sampling period of the study.

the same basic concepts used in the Moore (2000) model, and applies them in the vertical direction, similar to the approach taken in the deep Southern Ocean by Charette et al. (2007), describing the vertical transport of ${ }^{224} \mathrm{Ra}$, via turbulent diffusion, from its source on the sediment surface.

Assuming that the activity distribution of the radioactive tracer $\mathrm{Ra}(A)$ in the water column is controlled by inputs, transport and radioactive decay (with decay constant $\lambda$ ), the change in Ra activity over time $(\mathrm{d} A / \mathrm{d} t)$ is described using a general diffusion equation with an additional decay term,

$\frac{\mathrm{d} A}{\mathrm{~d} t}=K_{Z} \frac{\partial^{2} A}{\partial z^{2}}-\lambda A$.

Here, $z$ represents the vertical distance from the sediment surface. The 1-D diffusion model is applied in the vertical direction and assumed to have a single constant source of Ra, with activity $A_{0}$, at the lower boundary representing the sediment surface $(z=0)$. Radium is mixed away from the surface by turbulent diffusion at a constant rate $K_{Z}$. The activity will drop to 0 at some distance from the source $(A \rightarrow 0$ as $z \rightarrow \infty)$. Assuming steady-state, the vertical distribution of $A$ is described by

$A(z)=A_{0} e^{\left[-z \sqrt{\lambda / K_{Z}}\right]}$,
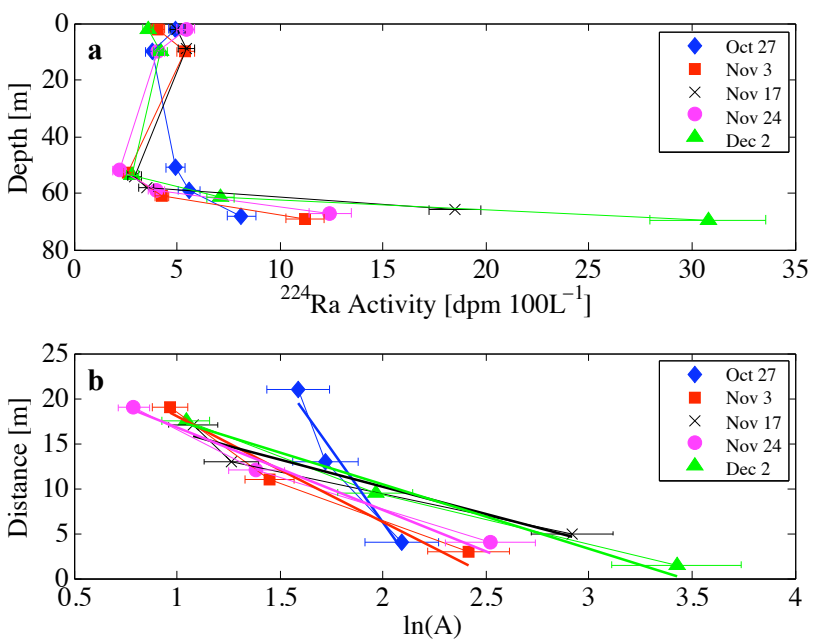

Fig. 5. (a) Vertical profiles of ${ }^{224}$ Radium. Black dashed box indicates deep-water samples used in the 1-D diffusive model. (b) Natural logarithm (ln) transformations of ${ }^{224} \mathrm{Ra}$ activity plotted as a function of distance from the sediment surface (dotted line). Each daily set of points is fit with a least-squares regression used to estimate mixing rates $\left(K_{Z}\right)$ and interface activities $\left(A_{0}\right)$. The different characteristics of the 26 October plot relative to all other days represents the different mixing regime during this period.

where $A(z)$ is the ${ }^{224} \mathrm{Ra}$ activity at depth $z$. Taking the natural $\log$ of Eq. (2) yields a linear equation of the ln of activity over depth:

$\ln (A(z))=\ln \left(A_{0}\right)-z \sqrt{\lambda / K_{Z}}$,

from which the slope $\left(\sqrt{\lambda / K_{Z}}\right)$ and intercept $(\ln (A(0))$ can be obtained by linear least-squares regression. The vertical eddy diffusion coefficient $\left(K_{Z}\right)$ can then be determined from the slope using knowledge of the ${ }^{224} \mathrm{Ra}$ decay constant $\left(\lambda=0.19 \mathrm{~d}^{-1}\right)$.

\subsection{Calculating benthic radium, carbon, oxygen, and nutrient fluxes}

By obtaining estimates of eddy diffusivity and interface activity, one can calculate the flux of Ra from a unit area of seafloor into the overlying water column. Integrating Eq. (2) over $z$ from 0 to $\infty$ yields:

$Q_{\mathrm{Ra}}=A_{0} \sqrt{\frac{K_{Z}}{\lambda}}$,

where $Q_{\mathrm{Ra}}$ is the benthic radium flux (atoms $\mathrm{Ra} \mathrm{m}^{-2} \mathrm{~s}^{-1}$ ).

Next, according to Fick's first law, combining the vertical concentration gradients $\left(\left[\mathrm{mmol} \mathrm{m}^{-3}\right] \mathrm{m}^{-1}\right)$ in carbon $(\mathrm{dDIC} / \mathrm{d} z)$ and oxygen $\left(\mathrm{dO}_{2} / \mathrm{d} z\right)$, with the Ra-derived eddy diffusivities $\left(K_{Z}\right)$, the vertical fluxes of carbon and oxygen per square meter of sediment surface $\left(\mathrm{mmol} \mathrm{m}^{-2} \mathrm{~d}^{-1}\right)$ can 
be computed for each sampling day:

$$
\begin{aligned}
& Q_{\mathrm{DIC}}=-K_{Z}\left[\frac{\mathrm{dDIC}}{\mathrm{d} z}\right] \\
& Q_{\mathrm{O}_{2}}=-K_{Z}\left[\frac{\mathrm{dO}_{2}}{\mathrm{~d} z}\right]
\end{aligned}
$$

Assuming negligible respiration within the deep-water column, a type II regression routine, which accounts for errors in both input variables, was used to determine the slopes

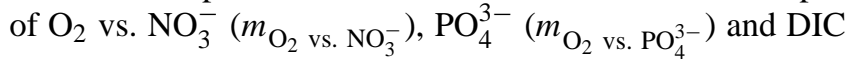
$\left(m_{\mathrm{O}_{2}}\right.$ vs. DIC). These slopes were applied to the oxygen flux $\left(Q_{\mathrm{O}_{2}}\right)$ in order to calculate the benthic nutrient fluxes, $Q_{\mathrm{NO}_{3}}$ and $Q_{\mathrm{PO}_{4}}\left(\mathrm{mmol} \mathrm{m}{ }^{-2} \mathrm{~d}^{-1}\right)$, respectively:

$$
\begin{gathered}
Q_{\mathrm{NO}_{3}^{-}}=\frac{Q_{\mathrm{O}_{2}}}{m_{\mathrm{O}_{2} \text { vs. } \mathrm{NO}_{3}^{-}}} \\
Q_{\mathrm{PO}_{4}^{3-}}=\frac{Q_{\mathrm{O}_{2}}}{m_{\mathrm{O}_{2} \text { vs. } \mathrm{PO}_{4}^{3-}}} .
\end{gathered}
$$

The uncertainties are reported for the majority of the values calculated in this analysis using the standard error propagation formula for uncorrelated variables. First, the uncertainty for each individual parameter (i.e. ${ }^{224} \mathrm{Ra}$, DIC) is determined. These values are then applied to the linear fits using a weighted least-squares regression routine in MATLAB, which fits the data while taking into account the uncertainties and provides a separate uncertainty in the resulting slope and intercept coefficients.

\subsection{Numerical simulations of the 1-D model}

The above application of the 1-D diffusion model to the ${ }^{224} \mathrm{Ra}$ data requires a steady-state assumption in order to analytically solve Eq. (1). However, by creating a timedependent 1-D finite difference model, we can solve this equation numerically, and in doing so, can test the steadystate assumption. Focusing on the deep basin, the finite difference model covers the bottom $40 \mathrm{~m}$ of the 70 -m-deep basin, and has a layer thickness of $0.5 \mathrm{~m}$. The model is set up by discretizing Eq. (1), and consists of 80 discrete points along a straight line, which extends out from the sediment surface $(z=0)$. Each point represents the center of a layer, and the activity or concentration in each layer progresses through time using the simple Euler forward approximation. Initially, the bottom $30 \mathrm{~m}$ of the water column is assumed to be fully mixed and set to an initial activity or concentration (e.g. $6 \mathrm{dpm} 100 \mathrm{~L}^{-1}$ for ${ }^{224} \mathrm{Ra}$ ) to represent the properties at the time of the deep-water intrusion event. For the ${ }^{224} \mathrm{Ra}$ run, $\mathrm{Ra}$ is set to a constant value $\left(A_{0}=22.5 \mathrm{dpm} 100 \mathrm{~L}^{-1}\right)$ at the bottom (assuming a constant source of Ra from the sediments) and is mixed upwards by turbulent diffusion, at a rate defined by $K_{Z}$. The model is run until the water-column activity distribution becomes relatively constant (i.e. the system reaches steady-state).

By removing the decay term, and modifying the finite source term, the model is also run for DIC and $\mathrm{O}_{2}$. A benthic source for DIC, and sink for $\mathrm{O}_{2}$ are imposed, as well as an additional term for water-column respiration, to assess the relative importance of these processes in the deep basin. For both DIC and $\mathrm{O}_{2}$, the model is run first with a single constant flux $\left(\mathrm{mmol} \mathrm{m} \mathrm{may}^{-1}\right)$ at the sediment surface. The fluxes used are $56 \mathrm{mmolDIC} \mathrm{m}^{-2} \mathrm{day}^{-1}$ and $-55 \mathrm{mmol} \mathrm{O}_{2} \mathrm{~m}^{-2}$ day $^{1}$, which are based on the results of this study. A second run then includes a constant, and vertically homogeneous, respiration term $\left( \pm 0.3 \mathrm{mmol} \mathrm{m}^{-3} \mathrm{~d}^{-1}\right)$, which adds an incremental amount of DIC to (or removes $\mathrm{O}_{2}$ from) each layer per time step. By assuming the intrusion event occurred just before the sampling period, the DIC and $\mathrm{O}_{2}$ distributions predicted by the model after a given number of days can be directly compared to the observations.

\section{Results}

\subsection{Radium distribution}

The vertical ${ }^{224} \mathrm{Ra}$ distributions during the six-week sampling period (Fig. 5) show relatively small activities in shallow and intermediate waters, with relatively large enrichments near the sediment surface. The ${ }^{224} \mathrm{Ra}$ signal in the upper $10 \mathrm{~m}$ of the water column can be attributed to the Sackville river, which discharges Ra-rich freshwater a few kilometres northeast of the sampling site. Variability in river discharge and the flushing effect of the daily tidal cycle may explain the minor variability between surface and shallow (10 m) samples (Fig. 5).

Focusing on deeper samples (Fig. 5b), significant ${ }^{224} \mathrm{Ra}$ enrichment was observed near the sediment surface in all 5 profiles, indicating a source of ${ }^{224} \mathrm{Ra}$ from the seafloor, similar to water-column observations in the deep Southern Ocean (Charette et al., 2007) and pore water results in many coastal environments (Hancock et al., 2006; Colbert and Hammond, 2008; Moore et al., 2011). Due to the ${ }^{224} \mathrm{Ra}$ isotope's short half-life $\left(t_{1 / 2}=3.66 \mathrm{~d}\right)$ and the quiescent nature of Bedford Basin's deep water, we observed a decrease in radium activity over a relatively short distance away from the sediments.

The application of the 1-D diffusive model, illustrated in Fig. 5b, yields $K_{Z}$ values ranging from $1.0-3.3 \mathrm{~cm}^{2} \mathrm{~s}^{-1}$, with uncertainties ranging from $25-30 \%$, with the exception of the 26 October profile, which yields a value of $25.7 \mathrm{~cm}^{2} \mathrm{~s}^{-1}$ with uncertainties near $100 \%$ (Table 1). The single outlier on 26 October was attributed to additional advective forces from a lateral intrusion event, violating the negligible advection assumption of the 1-D diffusive model. Therefore, the data were not used in further analysis (see Sect. "Discussion"). In 
Table 1. Results from ${ }^{224} \mathrm{Ra}$, carbon and oxygen analyses. Daily results of eddy diffusion coefficients $\left(K_{Z}\right)$, ${ }^{224} \mathrm{Ra}$ activities at the sedimentwater column interface $\left(A_{0}\right)$, as well as benthic fluxes of ${ }^{224} \mathrm{Ra}\left(Q_{\mathrm{Ra}}\right)$ and DIC $\left(Q_{\mathrm{DIC}}\right)$ out of the sediments (indicated by positive values) and fluxes of oxygen $\left(Q_{\mathrm{O}_{2}}\right)$ into the sediments (indicated by negative values), are shown.

\begin{tabular}{|c|c|c|c|c|c|}
\hline $\begin{array}{l}\text { Sampling } \\
\text { Date }\end{array}$ & $\begin{array}{r}\mathrm{K}_{Z} \\
\left(\mathrm{~cm}^{2} \mathrm{~s}^{-1}\right)\end{array}$ & $\begin{array}{r}A_{0} \\
\left(\mathrm{dpm} 100 \mathrm{~L}^{-1}\right)\end{array}$ & $\begin{array}{r}Q_{\mathrm{Ra}} \\
(\text { atoms m} \\
\end{array}$ & $\begin{array}{r}Q_{\mathrm{DIC}} \\
\left(\mathrm{mmol} \mathrm{m}{ }^{-2} \mathrm{~d}^{-1}\right)\end{array}$ & $\left(\mathrm{mmol} \mathrm{m}^{-2} \mathrm{~d}_{\mathrm{O}_{2}}\right)$ \\
\hline 26 Oct. $*$ & $25.7 \pm 24.3$ & $8.8 \pm 1.8$ & - & - & - \\
\hline 3 Nov. & $3.3 \pm 1.0$ & $11.9 \pm 2.2$ & $24.4 \pm 17.0$ & $19.9 \pm 11.6$ & $-36.5 \pm 18.8$ \\
\hline 17 Nov. & $1.0 \pm 0.3$ & $31.6 \pm 8.7$ & $35.5 \pm 18.0$ & - & - \\
\hline 24 Nov. & $1.9 \pm 0.5$ & $16.3 \pm 3.7$ & $25.5 \pm 7.3$ & $41.5 \pm 11.0$ & $-48.8 \pm 12.6$ \\
\hline 2 Dec. & $1.2 \pm 0.3$ & $30.3 \pm 8.1$ & $36.9 \pm 15.2$ & $58.7 \pm 15.5$ & $-44.1 \pm 11.6$ \\
\hline Mean & $1.8 \pm 0.6$ & $22.5 \pm 5.4$ & $30.6 \pm 14.6$ & & \\
\hline
\end{tabular}

*Values not included in flux analyses or mean calculations

general, however, the observed diffusivity remains relatively stable throughout the remainder of the sampling period.

\section{2 ${ }^{224} \mathrm{Ra}, \mathrm{DIC}, \mathrm{O}_{2}$ and nutrient fluxes}

The interpolated $\mathrm{Ra}$ activities at the sediment surface $\left(A_{0}\right)$ (see Eq. 3) range from $11.9-31.6 \mathrm{dpm} 100 \mathrm{~L}^{-1}$ with uncertainties ranging from $19-27 \%$ (Fig. 5b). Utilizing these estimates of daily $A_{0}$ along with the $K_{Z}$ values, we obtained daily radium fluxes $\left(Q_{\mathrm{Ra}}\right)$ that range from 24.4-36.9 atoms $\mathrm{Ra} \mathrm{m}^{-2} \mathrm{~s}^{-1}$. Uncertainties on this term varied significantly and in some cases were high (17-70\%) due to the cubic relationship of the slope term in the error propagation formula. These results are summarized in Table 1.

The overall trends seen in the vertical distributions of DIC and $\mathrm{O}_{2}$ in Bedford Basin (Fig. 6b, c) mimic those seen in the Ra observations, with clear vertical gradients near the sediment surface. No visible gradients, however, are seen in the deep-water $A_{\mathrm{T}}$ data (Fig. 6a). The DIC gradient also becomes increasingly negative throughout the study period (i.e. concentration decreases with distance from the sediments, see Fig. 6), while the opposing $\mathrm{O}_{2}$ gradient generally becomes increasingly positive. The vertical gradients in both DIC (Fig. 6d) and $\mathrm{O}_{2}$ (Fig. 6e) were quantified for each sampling day using a weighted least-squares regression of all data over the same depth ranges. The interpolation of the DIC linear regressions to the sediment surface yields a range of interface concentrations $\left(2199-2336 \mathrm{mmol} \mathrm{m}^{-3}\right.$, $2146-2280 \mu \mathrm{mol} \mathrm{kg}^{-1}$ ), which tend to increase considerably throughout the sampling period.

While estimates of $K_{Z}$ were made weekly throughout the sampling period, and weekly $\mathrm{O}_{2}$ profiles are consistently available from the Bedford Basin Monitoring Program, the DIC and $\mathrm{O}_{2}$ fluxes were calculated only for days where both DIC and ${ }^{224} \mathrm{Ra}$ observations were made. As seen in Table 1, both DIC and $\mathrm{O}_{2}$ fluxes strengthen, with opposing signs, throughout the majority of the sampling period. Assuming the changes in these fluxes occur linearly between sampling days, a linear interpolation between the flux values for the duration of the sample period ( 30 days) yields aver-
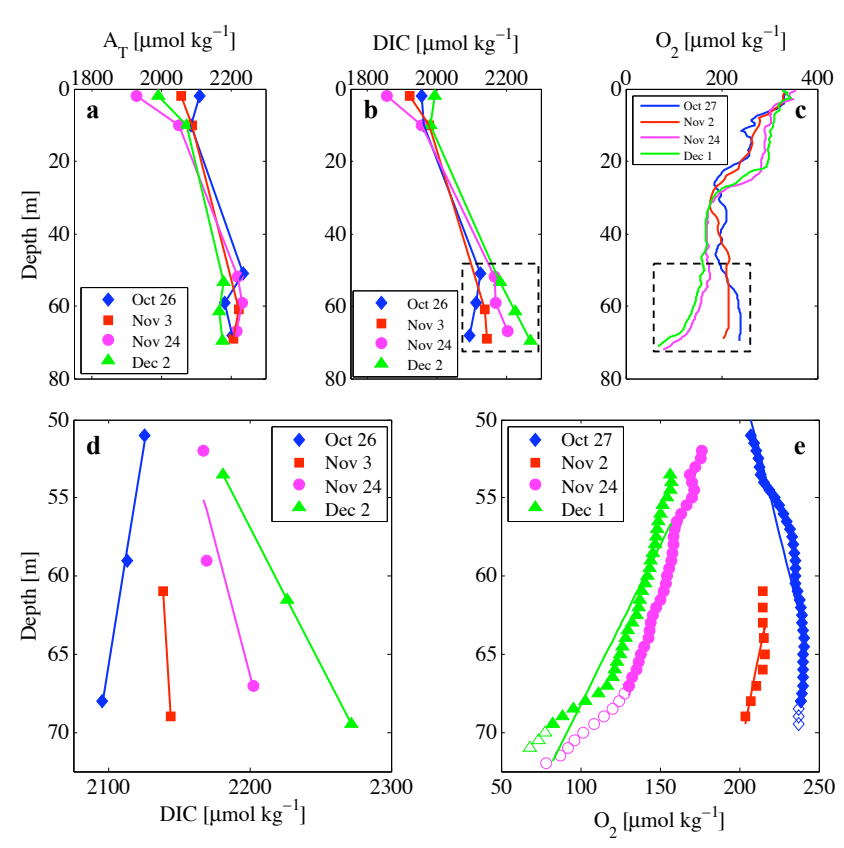

Fig. 6. Top: vertical profiles of $A_{\mathrm{T}}$ (a), DIC (b), and $\mathrm{O}_{2}$ (c) in Bedford Basin. Black dashed boxes indicate deep-water samples shown in bottom panels. Bottom: vertical profiles of DIC (d) and $\mathrm{O}_{2}(\mathbf{e})$ in deep waters with least-square regression lines indicating gradients. For deep-water $\mathrm{O}_{2}$ profiles (e), linear regressions are done over the same depth ranges as used for DIC (d) in order to be consistent with the depth ranges used to deduce the slopes. Open markers indicate deeper samples not used in the regressions. It is clear that the CTD-based $\mathrm{O}_{2}$ sensor provides a better resolution of the nearsediment gradients, which cannot be resolved with the $30 \mathrm{~L}$ Niskin bottle used for sampling DIC and ${ }^{224} \mathrm{Ra}$.

age fluxes of DIC and $\mathrm{O}_{2}$ of $35.8 \pm 11.9 \mathrm{mmol} \mathrm{DIC} \mathrm{m}^{-2} \mathrm{~d}^{-1}$ and $-43.7 \pm 15.1 \mathrm{mmol} \mathrm{O}_{2} \mathrm{~m}^{-2} \mathrm{~d}^{-1}$ respectively. Further independent DIC and $\mathrm{O}_{2}$ flux estimates were made by assessing the deep-water DIC and $\mathrm{O}_{2}$ inventory changes seen in Fig. 6. This inventory method yields average increases of $56.2 \mathrm{mmol} \mathrm{DIC} \mathrm{m}^{-2} \mathrm{~d}^{-1}$ and $-55.5 \mathrm{mmol} \mathrm{O}_{2} \mathrm{~m}^{-2} \mathrm{~d}^{-1}$. A third DIC flux estimate of $48.6 \pm 23.6 \mathrm{mmol} \mathrm{DIC} \mathrm{m}^{-2} \mathrm{~d}^{-1}$ 
can be made using the product of the Ra-based $\mathrm{O}_{2}$ flux and the $\mathrm{O}_{2}$ : DIC ratio defined using the slope in Fig. 7b. These latter approaches yield similar DIC flux values compared to the above Ra method ( $\left.35.8 \mathrm{mmolDIC} \mathrm{m}^{-2} \mathrm{~d}^{-1}\right)$, providing support for the flux estimates reported in this study. A comparison of the independently calculated DIC and $\mathrm{O}_{2}$ fluxes, and their corresponding DIC: $\mathrm{O}_{2}$ ratios, are shown in Table 2. It is important to note that the Ra-based estimates represent DIC and $\mathrm{O}_{2}$ fluxes obtained from individual profiles, while the inventory and ratio-based estimates require time series measurements. For the further context of this paper, we refer to the Ra-based DIC flux estimates.

The time series measurements of nitrate, phosphate and $\mathrm{O}_{2}$ taken at the Compass Buoy Site during the sampling period (Figs. 4 and 7a) show a decrease (i.e. consumption) in $\mathrm{O}_{2}$ at $60 \mathrm{~m}$ depth with increases (i.e. production) in both nitrate and phosphate. The plots of $\mathrm{O}_{2}$ vs. nitrate, phosphate and DIC, respectively (Fig. 7b), show similar trends, with increases in $\mathrm{NO}_{3}^{-}, \mathrm{PO}_{4}^{3-}$ and DIC with decreasing oxygen. These slopes are then used to calculate $\mathrm{O}_{2}: \mathrm{NO}_{3}^{-}$and $\mathrm{O}_{2}: \mathrm{PO}_{4}^{3-}$ ratios, which, using Eq. (7) and Eq. (8), yield nitrate $\left(Q_{\mathrm{NO}_{3}}\right)$ and phosphate $\left(Q_{\mathrm{PO}_{4}}\right)$ fluxes from the sediment into the water column of $4.27 \pm 1.50 \mathrm{mmol} \mathrm{NO}_{3}^{-} \mathrm{m}^{-2} \mathrm{~d}^{-1}$ and $0.32 \pm 0.17 \mathrm{mmol} \mathrm{PO}_{4}^{3-} \mathrm{m}^{-2} \mathrm{~d}^{-1}$ respectively. The relative uncertainties in these values differ due to the differing $R^{2}$ values of the linear fits. These nutrient fluxes and flux ratios are summarized in Table 3 , and combined with the carbon and oxygen estimates, now present a more complete and quantitative understanding of the transfer of important chemical constituents through the sediment-water interface in Bedford Basin.

\section{Discussion}

\section{1 $\quad K_{Z}$ measurements}

This study demonstrates the utility of water-column ${ }^{224} \mathrm{Ra}$ measurements in assessing vertical eddy diffusive coefficients using the simple 1-D diffusion model. The $K_{Z}$ values calculated in this study $\left(1.0-3.3 \mathrm{~cm}^{2} \mathrm{~s}^{-1}\right)$ fall within the lower end of the range of values $\left(1-100 \mathrm{~cm}^{2} \mathrm{~s}^{-1}\right)$ obtained during an extensive dye tracing experiment in coastal and estuarine waters around the UK (Riddle and Lewis, 2000). This is not surprising given the relatively quiescent nature of the deep waters of Bedford Basin. Although no prior estimates are available for Bedford Basin, similar models in other regions have produced similar $K_{Z}$ values. Charette et al. (2007) used the longer-lived ${ }^{228} \mathrm{Ra}$ isotope in a similar diffusion model to calculate a $K_{Z}$ of $1.5 \mathrm{~cm}^{2} \mathrm{~s}^{-1}$ in the intermediate waters (300-1000 m) of the Southern Ocean. Berelson et al. (1982) used ${ }^{222} \mathrm{Rn}$ in the 500-m-deep Santa Barbara basin to calculate a vertical diffusivity of $3.4 \mathrm{~cm}^{2} \mathrm{~s}^{-1}$, but also reported that near-bottom mixing caused difficulties in fitting the 1-dimensional model. Sarmiento et al. (1976)
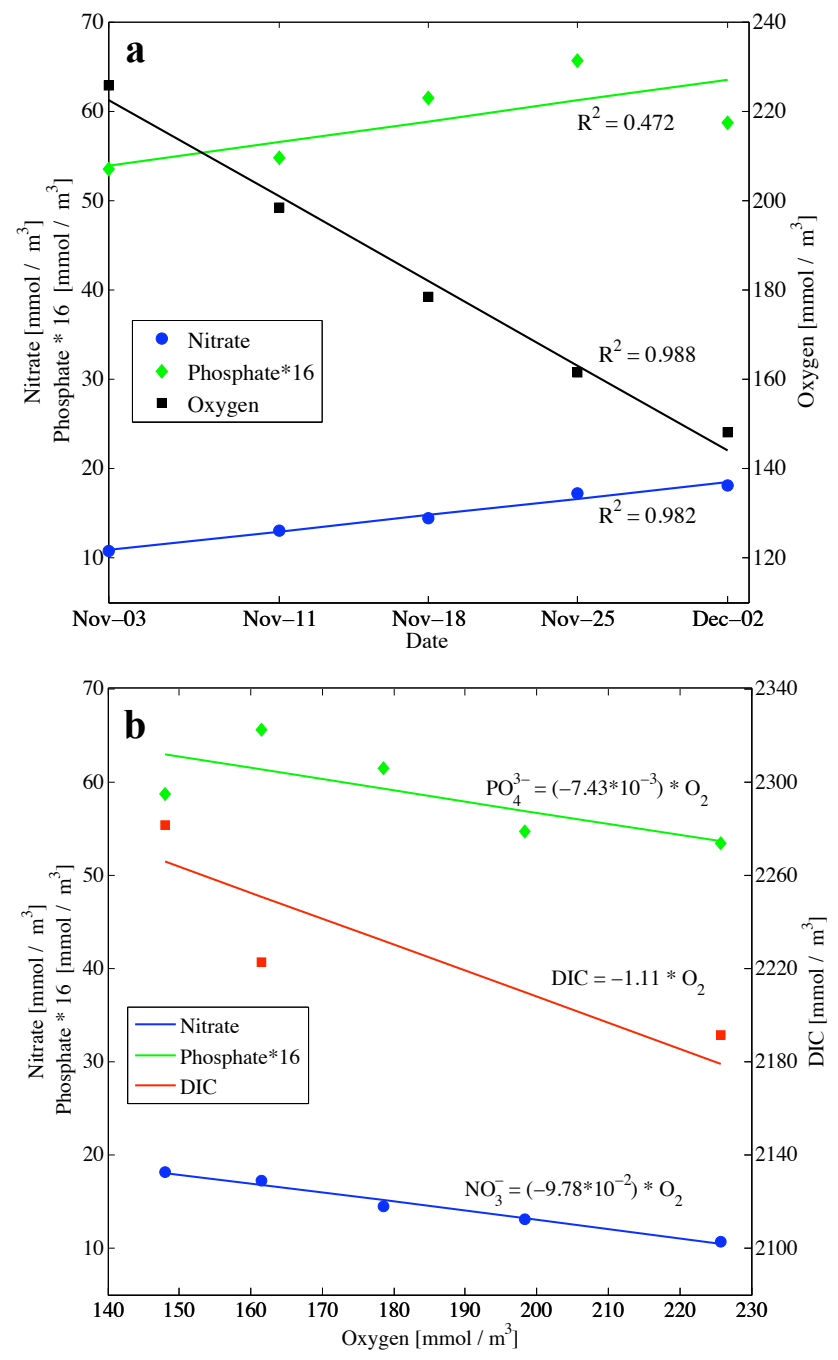

Fig. 7. (a) Time series measurements at $60 \mathrm{~m}$ in Bedford Basin during the sampling period (as shown in Fig. 4). The $R^{2}$ values represent the quality of the fit, which largely affects the uncertainties in the final flux estimates. (b) Deep-water $(60 \mathrm{~m}) \mathrm{O}_{2}$ vs. $\mathrm{NO}_{3}^{-}, \mathrm{PO}_{4}^{3-}$ and DIC. Flux ratios (listed in Table 3) are shown as the slopes of the linear regression curves. Note that phosphate regression coefficients are from the original data rather than "Phosphate*16", which is shown to better illustrate the parallel nature of the nitrate and phosphate slopes.

measured vertical profiles of both ${ }^{228} \mathrm{Ra}$ and ${ }^{222} \mathrm{Rn}$ during two GEOSECS expeditions and used a 1-D diffusion model to calculate values of $K_{Z}$ between $5-440 \mathrm{~cm}^{2} \mathrm{~s}^{-1}$ in the deep Atlantic and Pacific Oceans. As is mentioned by Sarmiento et al. (1976), estimates of $K_{Z}$ can vary by orders of magnitude when comparing different regions or approaches. Therefore, caution must be taken when directly comparing the observed results here to those found in other regions, or calculated using different methods, due to variations in numerous important factors, including sediment characteristics. 
Table 2. Comparison of calculated DIC fluxes out of sediments (i.e. positive fluxes), $\mathrm{O}_{2}$ fluxes into sediments (i.e. negative values), and resulting $\mathrm{O}_{2}$ : DIC flux ratios.

\begin{tabular}{lrrr}
\hline & $\begin{array}{r}\text { Radium Method } \\
\text { (Fig. 6) }\end{array}$ & $\begin{array}{r}\text { Inventory Method } \\
\text { (see Sect. 3.2) }\end{array}$ & $\begin{array}{r}\mathrm{O}_{2} \text { Slope Method } \\
\text { (Fig. 7b) }\end{array}$ \\
\hline$Q_{\mathrm{DIC}}\left(\mathrm{mmol} \mathrm{c} \mathrm{m}^{-2} \mathrm{day}^{-1}\right)$ & 35.8 & 56.2 & N/A \\
$Q_{\mathrm{O}_{2}}\left(\mathrm{mmol} \mathrm{O}_{2} \mathrm{~m}^{-2} \mathrm{day}^{-1}\right)$ & -43.7 & -55.5 & N/A \\
$\mathrm{O}_{2}:$ DIC & -1.22 & -0.99 & -0.90 \\
\hline
\end{tabular}

Table 3. Chemical fluxes in Bedford Basin.

(a) Fluxes of DIC, $\mathrm{O}_{2}$ and nutrients, with respective flux ratios

\begin{tabular}{lrrr}
\hline Fluxes from Sediment* & \multicolumn{3}{c}{ Ratios** $^{* *}$} \\
\hline DIC $\left(Q_{\text {DIC }}, \text { Radium Method }\right)^{\mathrm{a}}$ & $35.8 \pm 11.9 \mathrm{mmol} \mathrm{m}^{-2} \mathrm{day}^{-1}$ & $\mathrm{O}_{2}: \mathrm{DIC}$ & $-0.9 \pm 0.3$ \\
Oxygen $\left(Q_{\mathrm{O}_{2}}, \text { Radium Method }\right)^{\mathrm{a}}$ & $-43.7 \pm 15.1 \mathrm{mmol} \mathrm{O}_{2} \mathrm{~m}^{-2} \mathrm{day}^{-1}$ & $\mathrm{DIC}^{\mathrm{N} O}$ & $11.4 \pm 4.0$ \\
Nitrate $\left(\mathrm{NO}_{3}^{-}\right)\left(Q_{\mathrm{NO}_{3}}\right)^{\mathrm{b}}$ & $4.27 \pm 1.50 \mathrm{mmol} \mathrm{N} \mathrm{m}^{-2} \mathrm{day}^{-1}$ & $\mathrm{DIC}: \mathrm{PO}_{4}^{3-}$ & $150 \pm 80.5$ \\
Phosphate $\left(\mathrm{PO}_{4}^{3-}\right)\left(Q_{\mathrm{PO}_{4}}\right)^{\mathrm{c}}$ & $0.32 \pm 0.17 \mathrm{mmol} \mathrm{P} \mathrm{m}^{-2} \mathrm{day}^{-1}$ & $\mathrm{O}_{2}: \mathrm{NO}_{3}^{-}$ & $-10.2 \pm 0.7$ \\
& & $\mathrm{O}_{2}: \mathrm{PO}_{4}^{3-}$ & $-134.6 \pm 55.7$ \\
& & $\mathrm{NO}_{3}^{-}: \mathrm{PO}_{4}^{3-}$ & $13.1 \pm 5.5$ \\
\hline
\end{tabular}

\begin{tabular}{|c|c|}
\hline (b) Carbon Fluxes in the Surface Layer & $\mathrm{mmol} \mathrm{C} \mathrm{m}^{-2} \mathrm{day}^{-1}$ \\
\hline DIC Uptake by Primary Production ${ }^{\mathrm{d}}$ & -50.1 \\
\hline DIC from Sackville River ${ }^{\mathrm{e}}$ & 14.5 \\
\hline OrgC from Sackville River ${ }^{\mathrm{f}}$ & 0.38 \\
\hline OrgC from Sewage Outfallg & 0.22 \\
\hline
\end{tabular}

*During the 30 day sampling period (3 November-2 December 2010). Positive values indicate fluxes out of sediments while negative values indicate fluxes into sediments.

** Calculated using slopes of $\mathrm{O}_{2}$ vs. $\mathrm{NO}_{3}^{-} / \mathrm{PO}_{4}^{3-} / \mathrm{DIC}$ (see Fig. 7b).

a Average of linearly interpolated $Q_{\mathrm{DIC} / \mathrm{O}_{2}}$ values (Table 1).

${ }^{\mathrm{b}}$ Product of $Q_{\mathrm{O}_{2}}$ and $\mathrm{O}_{2}: \mathrm{NO}_{3}^{-}$ratio.

${ }^{\mathrm{c}}$ Product of $Q_{\mathrm{O}_{2}}$ and $\mathrm{O}_{2}: \mathrm{PO}_{4}^{3-}$ ratio.

${ }^{\mathrm{d}}$ Daily average from Platt (1975).

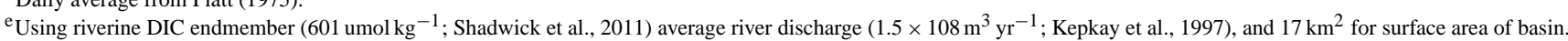

${ }^{f}$ From Hargrave and Taguchi (1978).

g Converted from CBOD data provided by Mill Cove Wastewater Treatment Plant (WWTP).

Estimates of these coefficients in Bedford Basin will facilitate a number of useful applications in the future. For example, the mixing schemes of physical models in general are often tuned using a wide range of acceptable mixing coefficients from other published literature. Therefore, observational estimates of coefficients like eddy diffusion on a small scale, like the ones reported here, can be very useful in areas where physical models are in place. In this case, the observed diffusivities are useful to validate and improve the vertical mixing scheme of the coastal circulation model for Halifax Harbour (Shan et al., 2011). Furthermore, these estimates can be directly used to fine-tune the vertical eddy diffusivity coefficient, used as an input parameter for the random walk process in the recently implemented particle tracking model for Halifax Harbour (Shan and Sheng, 2013).

\subsection{Deep-water intrusion}

The results here reveal distinct benthic releases of ${ }^{224} \mathrm{Ra}$, DIC, and nutrients from the sediment, with a corresponding consumption of $\mathrm{O}_{2}$. For this study, the substantial deepwater intrusion, which, in effect, reset the chemical gradients in the deep basin, provided a rare opportunity to monitor the reestablishment of the near-bottom biogeochemical gradients throughout the sampling period. The intrusion event appears to have taken place just prior to the initial sampling day (26 October), affecting the entire deep-water column (Figs. 2 and 4). At this time, very little gradient in ${ }^{224} \mathrm{Ra}$ is observed and the inferred vertical diffusivity of $25.7 \mathrm{~cm}^{2}$ $\mathrm{s}^{-1}$ is an order of magnitude higher than those calculated for all subsequent profiles in this study (Table 1; Fig. 5). This observation suggests the presence of enhanced vertical mixing due to the intrusion event. In a recent study by $\mathrm{Li}$ and Cai (2011), the same 1-D diffusion model, as is used here, 
is shown to be very sensitive to advection, with the maximum sensitivity occurring when values of $K_{Z}$ are small, and when using the shorter-lived isotope (i.e. ${ }^{224} \mathrm{Ra}$ ). The large relative uncertainty calculated in this instance for $K_{Z}$ (95\%) likely reflects the sensitivity to small $K_{Z}$ values and advective signals. The immediate effects of the lateral intrusion are also visible in the biogeochemical data collected on 27 October, namely the abrupt increases in deep-water $\mathrm{O}_{2}$ and particulate organic carbon (POC) levels and corresponding decreases in nutrients (Fig. 4), which indicate the intrusion originated from near the surface. The temperature and salinity properties (Fig. 2) of the deep basin during this time reveal a shift to warmer, more saline water immediately following the event, suggesting a shallow, offshore intrusion source, which is consistent with the mechanism described for these intrusion events (Platt, 1975). As a whole, the data in late October indicate a relatively well-mixed deep-water column as a result of a lateral intrusion of a water mass rich in oxygen and POC, and depleted in DIC and nutrients.

The observations throughout the remainder of the sampling period illustrate a re-stabilization of the water column after the intrusion event. The increasing magnitude of the vertical radium gradient after 27 October (Fig. 5) results in an initial decrease and eventual stability of calculated $K_{Z}$ values over time. However, while decreases in the diffusive coefficients will tend to dampen the flux terms (Eqs. 5 and 6), the intensification of the vertical DIC and $\mathrm{O}_{2}$ gradients cause the magnitude of the DIC and $\mathrm{O}_{2}$ fluxes to increase considerably throughout November 2010. These trends can be attributed to the processes that occur after the lateral intrusion event, namely the settling of intruded sedimentary material and the biogeochemical reactions that take place within the sediments after deposition. For example, a sharp increase in POC levels at $60 \mathrm{~m}$ water depth on 27 October (Fig. 4), followed by its decline one week later, indicate enhanced delivery and settling of POC on the seafloor, eventually fuelling chemical reactions within the sediments.

The substantial intrusion of warm, salty, and therefore relatively dense water (Fig. 2) into the deep basin almost every fall season (Fig. 3) is an event which, to date, has not received extensive scientific attention. The event in 2010 marks the annual temperature and salinity maximum for the deep basin waters, with cooling, freshening and oxygen depletion occurring throughout the following fall and winter.

\subsection{Remineralization of organic material}

While the calculated fluxes (Table 3) indicate clear sources and sinks of various chemical constituents, the ratios of these fluxes can provide further insight into the origin of the organic material and allow us to speculate about the dominant pathways for remineralization. The observations seen here (Fig. 7b; Table 3) are consistent with the general notion of benthic respiration as a source of the various chemical constituents released from sediments. An assumption of negligi- ble water-column respiration in the deep basin is made based on the short residence time of sinking organic particles in the deep basin waters. Organic particles tend to sink through the water column at velocities ranging from a few meters, to hundreds of meters per day (Armstrong et al., 2009), and within Bedford Basin, particle sinking rates observed at $70 \mathrm{~m}$ depth ranged from $\sim 5-170 \mathrm{~m}$ per day (Syvitski et al., 1995). Even when considering the lower end of these ranges, organic particles spend little time in the deep-water column before reaching the sediments.

Conceptually, the overall net reaction of benthic respiration, describes the degradation of organic matter by bacteria within the sediments resulting in both the consumption of $\mathrm{O}_{2}$, or other electron acceptors, and the formation of DIC (Burdige, 2011). Subsequently, DIC, along with Ra, diffuse into the water column, while oxygen diffuses into the sediment. The result is a water-column flux of DIC away from sediments and an opposing flux of $\mathrm{O}_{2}$ into the sediment. The effect of these opposing fluxes can be observed in the vertical DIC and $\mathrm{O}_{2}$ distributions of Bedford Basin (Fig. 6).

According to the concepts first described by Redfield et al. (1963), marine organic matter contains carbon, nitrogen and phosphorus in the average composition of $\mathrm{C}: \mathrm{N}: \mathrm{P}=106: 16: 1$. Therefore, the net oxidation of this material to $\mathrm{DIC}, \mathrm{NO}_{3}^{-}$and $\mathrm{PO}_{4}^{3-}$ by bacteria within sediments should produce similar ratios in the pore water, with an $\mathrm{O}_{2}$ : DIC flux across the sediment water interface nearing $-1.3: 1$ (Jahnke and Jahnke, 2000). The Bedford Basin observations (Fig. 7b) suggest an $\mathrm{O}_{2}$ : DIC ratio of $-0.9 \pm 0.3$ : 1 for benthic fluxes, while $\mathrm{DIC}: \mathrm{NO}_{3}^{-}: \mathrm{PO}_{4}^{3-}$ ratios are approximately $150: 13: 1$ (Table 3 ). These ratios are a strong indication that bacterial respiration of marine organic matter within the sediments fuels the benthic fluxes into the overlying water column. However, remineralization of organic matter can occur via a number of pathways, involving reactions that result in deviations from the Redfield values, most importantly, denitrification.

The reactions governing the respiration of POM in sediments will depend on the availability of various electron acceptors, with $\mathrm{O}_{2}$ being most favourable in terms of energy gained (Burdige, 2011). The surface sediment at the Compass Buoy Station is considered to be a poorly oxygenated, fine-grained mud, with very high organic carbon content (OCC $=5-6 \%$ ) (Fader and Miller, 2008; Buckley and Hargrave, 1989). Therefore, aerobic oxidation will tend to dominate within the thin oxygenated layer of sediment directly beneath the sediment-water interface. Beneath this layer, in the absence of $\mathrm{O}_{2}$, the system can be assumed to favour the reduction of $\mathrm{NO}_{3}^{-}$(denitrification), resulting in a conversion of $\mathrm{NO}_{3}^{-}$to elemental $\mathrm{N}_{2}$, and the production of $A_{\mathrm{T}}$ (Chen and Wang, 1999). Similarly, in the absence of available $\mathrm{NO}_{3}^{-}$, the reduction of manganese, iron and sulphate will produce $\mathrm{Mn}^{2+}, \mathrm{Fe}^{2+}$ and $\mathrm{H}_{2} \mathrm{~S}$, respectively, also increasing $A_{\mathrm{T}}$ by varying amounts (Chen and Wang, 1999). 
However, ignoring the potential burial of pyrite, upward diffusion of these reduced products into the oxygenated sediment layer will result in their reoxidation, with the corresponding $A_{\mathrm{T}}$ consumed. In this case, without any direct measurements of the sediment biogeochemistry, the extent of most anaerobic reactions is not fully traceable. For denitrification, however, the reaction produces DIC and $A_{\mathrm{T}}$ while creating an irreversible loss of $\mathrm{NO}_{3}^{-}$from the system in the form of $\mathrm{N}_{2}$, which should, in effect, increase the DIC: $\mathrm{NO}_{3}^{-}$, and $\mathrm{O}_{2}: \mathrm{NO}_{3}^{-}$ratios of the observed fluxes. The observed DIC : $\mathrm{NO}_{3}^{-}$ratio of $11.4: 1$ is considerably higher than Redfield values $(6.6: 1)$, and those previously reported for both deposited and suspended particulate matter in sediment traps in Bedford Basin by Hargrave and Taguchi (1978). Overall, observed DIC: $\mathrm{NO}_{3}^{-}$and $\mathrm{NO}_{3}^{-}: \mathrm{PO}_{4}^{3-}$ flux ratios indicate a deficit of $\mathrm{NO}_{3}^{-}$(e.g. $\mathrm{NO}_{3}^{-}$: $\mathrm{PO}_{4}^{3-}<16$ ) suggesting that denitrification plays a role in the respiration of POM within the sediments. However, no increase in $A_{\mathrm{T}}$ is observed in the water column (Fig. 6a), despite the fact that denitrification produces $0.99 \mathrm{~mol} A_{\mathrm{T}}$ per $1 \mathrm{~mol} \mathrm{~N}$ denitrified (Chen and Wang, 1999). This $A_{\mathrm{T}}$ signal may be masked by the aerobic processes occurring in the oxygenated sediment layers. Also, considering the much larger water-column background of $A_{\mathrm{T}}$ $\left(\sim 2200 \mathrm{mmol} \mathrm{m}^{-3}\right)$ compared to $\mathrm{NO}_{3}^{-}\left(\sim 10 \mathrm{mmol} \mathrm{m}^{-3}\right)$, a weak $A_{\mathrm{T}}$ signal produced by denitrification may not be discernable in the observations.

The observed oxygen fluxes represent considerable rates of sediment oxygen uptake, given the generally low temperature of the water column. Given the high organic carbon content and anoxic characteristics of the Bedford Basin sediment, the substantial intrusion of oxygenated waters could facilitate increased oxygen uptake during the sampling period. Hargrave (1978) used incubations of undisturbed sediment cores collected in the deep basin to calculate annual mean oxygen uptake values of $17 \mathrm{mmol} \mathrm{O}_{2} \mathrm{~m}^{-2} \mathrm{~d}^{-1}$. While deep-water temperatures in the basin are similar in both studies, no deep-water oxygen intrusion is reported in the Hargrave (1978) study, possibly explaining the factor of 2.5 difference between their results, and those reported here. In fact, the results are quite comparable given the vast differences in analytical techniques and general methodologies between these two studies. Hargrave (1978) also reported a 1-2 month delay in peak sediment oxygen uptake after deposition of fresh organic matter by the spring bloom, similar to the observations seen here in the fall. This delayed response in benthic ecosystems has also been observed in laboratory studies (Ståhl et al., 2004) and in other coastal environments (Rudnick and Oviatt, 1986). Finally, very little benthic biomass has been reported in the deep basin $\left(7 \pm 12 \mathrm{~g} \mathrm{~m}^{-2}\right)$, indicating that bioturbation and bioirrigation are likely not key contributors to the oxygen uptake observations made here (Hargrave et al., 1989).

\subsection{Numerical model results}

In order to better understand the validity of the steady-state assumption, we attempted to reproduce the ${ }^{224} \mathrm{Ra}$, DIC and $\mathrm{O}_{2}$ observations using a time-dependent finite-difference diffusion model. The model is initialized with a constant intrusion activity of $6 \mathrm{dpm} 100 \mathrm{~L}^{-1}$ over the bottom $30 \mathrm{~m}$ of the water column, and $1 \mathrm{dpm} 100 \mathrm{~L}^{-1}$ in the upper water column. The model is run with the mean observed mixing rate $\left(K_{Z}=1.84 \mathrm{~cm}^{2} \mathrm{~s}^{-1}\right)$ and the mean observed interface activities $\left(A_{0}=22.5 \mathrm{dpm} 100 \mathrm{~L}^{-1}\right)$, listed in Table 1. Overall, the large majority of the ${ }^{224} \mathrm{Ra}$ observations fall within the error margins of the $K_{Z}$ and $A_{0}$ terms (see Fig. 8a and b), indicating that the assumptions used in the 1-D diffusion model are consistent with the observations from Bedford Basin. According to the time-dependent model, a steady-state Ra distribution is reached within approximately 7 days of the intrusion event, which is reasonable given the short half-life of ${ }^{224} \mathrm{Ra}$. Therefore, a steady-state, which is assumed for the 1-D diffusion model, is likely present throughout a large majority of the sampling period. Furthermore, the fit of the numerical model to the observations is encouraging given the exclusion of any horizontal mixing or secondary Ra sources from the model runs.

Assuming the same diffusive mixing rate as described above, the model results for DIC and $\mathrm{O}_{2}$ are shown in Fig. 8c-f. The initial concentrations in the model were based on the 27 October observations, with intrusion concentrations for the bottom $30 \mathrm{~m}$ of $2165 \mathrm{mmol} \mathrm{DIC} \mathrm{m}^{-3}$ and $240 \mathrm{mmol} \mathrm{O}_{2} \mathrm{~m}^{-3}$, and concentrations in the upper water column of $2190 \mathrm{mmol} \mathrm{DIC} \mathrm{m}^{-3}$ and $180 \mathrm{mmol} \mathrm{O}_{2} \mathrm{~m}^{-3}$. The models were run with constant fluxes of $56 \mathrm{mmol} \mathrm{DIC} \mathrm{m}^{-2} \mathrm{day}^{-1}$ and $-55 \mathrm{mmol} \mathrm{O}_{2} \mathrm{~m}^{-2}$ day $^{-1}$, which are based on the inventory method results listed in Table 2 . When run with only a constant benthic flux, the finitedifference numerical model provides a relatively good fit to the observations (see Fig. 8c and d), with the only significant deviations from the observations occurring near the sediments. The model consistently predicts too little DIC, and too much $\mathrm{O}_{2}$ in the later stages of the sampling period.

In order to test whether these deviations of the model results from the observations were due to the omission of water-column respiration, we added a constant water-column respiration rate to the model, which in turn would cause a gradual build-up of water-column DIC, with a corresponding loss of $\mathrm{O}_{2}$, over time. Assuming a DIC : $\mathrm{O}_{2}$ ratio of $1: 1$, this term added $0.3 \mathrm{mmolDIC} \mathrm{m}^{-3} \mathrm{day}^{-1}$ to each layer, or removed $\mathrm{O}_{2}$ at a rate of $-0.3 \mathrm{mmol} \mathrm{O}_{2} \mathrm{~m}^{-3}$ day $^{-1}$. This chosen respiration rate is small compared to prior estimates on the nearby Scotian Shelf (Thomas et al., 2012), and lies in the low end of the range $\left(0.02-75 \mathrm{mmol} \mathrm{O}_{2} \mathrm{~m}^{-3}\right.$ day $\left.^{-1}\right)$ listed in a global compilation study of water-column respiration rates (Robinson and Williams, 2005). Assuming homogenous respiration over the bottom $40 \mathrm{~m}$, this water-column respiration term (12 mmol DIC m $\left.{ }^{-2} \mathrm{day}^{-1}\right)$ represents approximately 

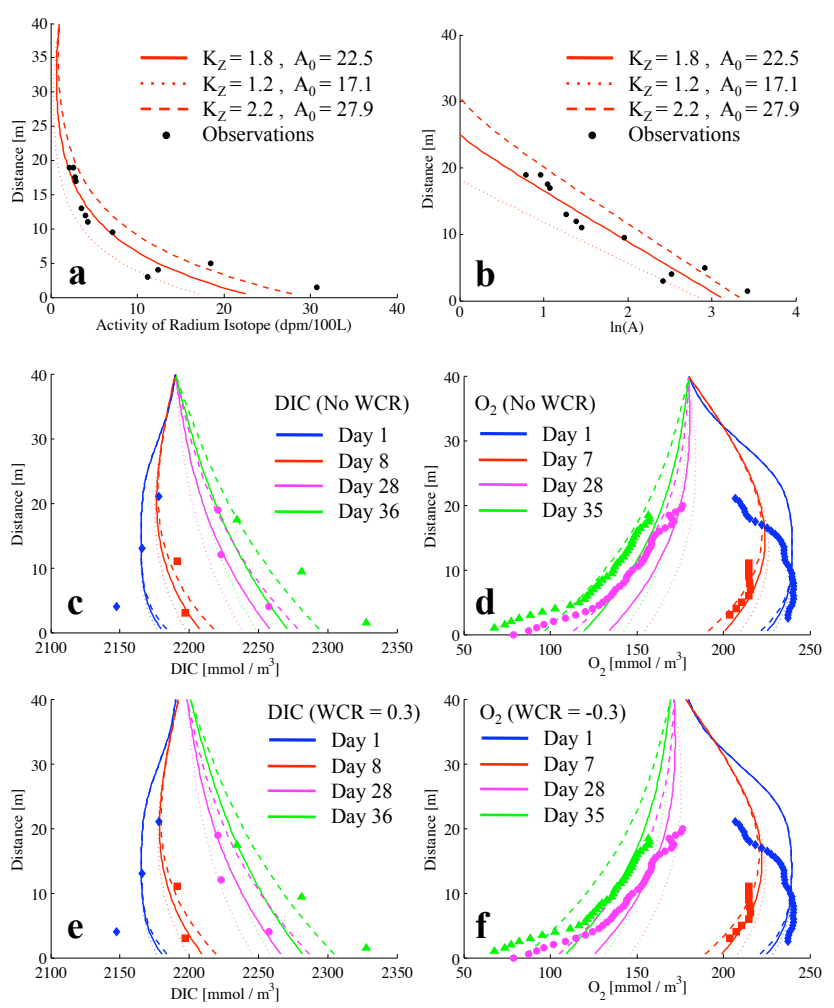

Fig. 8. Finite difference model results. (a) Vertical ${ }^{224} \mathrm{Ra}$ distribution at steady-state. (b) Natural log of activity with distance from sediment at steady-state. Results after 30-day runs are shown (steady-state reached within 7 days). Dashed and dotted lines show error margins given the uncertainties in $K_{Z}$ and $\mathrm{A}_{0}$ (see Table 1). (c) DIC and (d) $\mathrm{O}_{2}$ distributions for different days following an intrusion event (with no water-column respiration (WCR) term). (e) DIC and (f) $\mathrm{O}_{2}$ distributions with WCF term added. Assuming a $25 \%$ uncertainty on the benthic flux values, the lower (dotted line) and upper (dashed line) uncertainty ranges are shown. Observations are overlaid as discrete points, with model run days matching the sampling days given an intrusion event beginning on 26 October (see Fig. 6).

$20 \%$ of the benthic flux term $\left(56 \mathrm{mmol} \mathrm{m}^{-2}\right.$ day $\left.^{-1}\right)$. The addition of the water-column respiration term provides a slightly better fit to some of the observations (see Fig. 8e and f), but the required magnitude of this term to obtain an improved fit is small, suggesting its contribution to the system is minor, if not negligible. Any further investigation into the relative effects of water-column respiration goes beyond the scope of this paper and the capacity of the current dataset.

In this study, the model is applied in order to assess the non-steady state behavior of the carbon and oxygen systems during the sampling period, and test the assumptions regarding the neglect of water-column respiration in the 1-D diffusion model. Overall, this time-dependent 1-D model, which illustrates the diffusion of a benthic signal into the water column, is able to reproduce the general trends in both the DIC and $\mathrm{O}_{2}$ observations, indicating that the benthic release of
DIC and uptake of $\mathrm{O}_{2}$ are the dominant processes shaping their distributions in the deep basin.

\subsection{Carbon budgets}

Considering the short period over which these fluxes are measured (30 days), they constitute substantial additions to the carbon inventory of the basin (Table 3). For example, the Sackville River, on average, delivers only $14.5 \mathrm{mmolDIC} \mathrm{m}^{-2} \mathrm{~d}^{-1}$ to the surface waters of Bedford Basin (Table 3), which corresponds to less than half of the daily benthic DIC release into the deep-water column. Furthermore, when integrating over the 30-day sampling period, the benthic DIC return flux corresponds to approximately $6 \%$ of the annual DIC uptake by primary production in the surface waters (Platt, 1975). While similarly large benthic DIC contributions have been reported previously (Chen and Wang, 1999; Jahnke et al., 2005), they are more common in warmer, shallower shelf environments. In such environments, the euphotic zone is in close proximity to sediments allowing large amounts of organic carbon formed in the surface to reach the sediments, where the organic carbon is respired rapidly. A sediment trap study in the basin by Hargrave and Taguchi (1978) provided annual mean organic carbon sedimentation rates at $60 \mathrm{~m}$ depth of $17 \mathrm{mmol} \mathrm{C} \mathrm{m}^{-2} \mathrm{~d}^{-1}$, approximately half of the DIC return flux calculated here during the sampling period. Therefore, even when assuming no long-term burial of sedimented material, our results represent enhanced benthic carbon fluxes compared to those reported by Hargrave and Taguchi (1978). Allochthonous inputs of organic material from rivers and sewage appear to play a very modest role in organic carbon supply to Bedford Basin (Hargrave et al., 1976; Table 3), and allow the episodic ventilation events to sustain oxic conditions in the deep basin (Fig. 3). This is in line with our observed flux ratios, which point to the respiration of marine organic matter, rather than other organic materials.

POC concentrations increased in the deep waters following the intrusion event in late October (Fig. 4). As argued by Hargrave and Taguchi (1978), an inflow of dense surface water, rich in labile POM and re-suspended sediments, could import the additional organic material necessary to fuel the benthic fluxes we observe. Furthermore, the occurrence of the autumn bloom in mid-October (Fig. 4) may have led to organic carbon delivery both vertically via increased particle export from the surface layer (Fig. 4) and laterally via the deep-water intrusion. Regardless of the delivery mechanism, the observations indicate that an enhanced supply of organic matter becomes available for rapid respiration, which is reflected by the high return fluxes we observe. It is important to note that these fluxes may occur over a short time period and do not necessarily reflect the annual mean fluxes. While the notion of enhanced delivery of POM to the deep basin via lateral intrusion appears reasonable, direct observations of these rare events are needed to completely understand their impact 
on the chemical budgets, as well as the physical structure, of Bedford Basin.

\section{Conclusions}

Corresponding trends between various hydrochemical measurements point to enhanced benthic respiration and subsequent pore water fluxes of DIC, $\mathrm{O}_{2}$, and nutrients into the deep-water column of Bedford Basin, paralleled by a release of ${ }^{224} \mathrm{Ra}$. The application of the 1-D diffusion model to nearbottom distributions of ${ }^{224} \mathrm{Ra}$ was useful in understanding the evolving mixing regime of the deep basin following a considerable water-exchange event, and yielded vertical eddy diffusivities and fluxes. Fluxes of DIC, nutrients and $\mathrm{O}_{2}$, consistent in magnitude with Redfield ratios, point to benthic respiration of marine organic matter. Only a minor discrepancy in results from field observations, and those obtained using numerical simulations, indicate that the assumptions of the 1-D diffusion model are consistent with the ${ }^{224} \mathrm{Ra}$ observations in Bedford Basin. Interpolation throughout the 30-day sampling period yields a benthic DIC return flux, which constitutes as much as $6 \%$ of the annual primary production in surface waters. This presumed short-term substantial flux is believed to result from enhanced delivery of particulate organic carbon (POC) to deep waters associated with the co-occurrence of the autumn bloom and a deep-water intrusion event.

High seasonal variability in sedimentation rate and relatively high carbon sedimentation rates during fall months have been reported by Hargrave and Taguchi (1978). Longterm $\mathrm{Ra}$ and carbon monitoring would be needed in order to gain better understanding of the mixing regimes and benthic fluxes at an annual scale.

Acknowledgements. We thank John Smith, Jeff Spry, Kevin Pauley, the crew of the CCGS Sigma T, as well as Bill Li and the DFO Bedford Basin Plankton Monitoring Program. This work contributes to IGBP/IHDP LOICZ. We also thank the 2 anonymous referees, whose comments have substantially improved the manuscript.

Edited by: T. Treude

\section{References}

Armstrong, R. A., Peterson, M. L., Lee, C., and Wakeham, S. G.: Settling velocity spectra and the ballast ratio hypothesis, DeepSea Res. Part II, 56, 1470-1478, 2009.

Berelson, W. M., Hammond, D. E., and Fuller, C.: Radon-222 as a tracer for mixing in the water column and benthic exchange in the southern California borderland, Earth Planet. Sci. Lett., 61, 41-54, 1982.

Berelson, W. M., Hammond, D. E., and Johnson, K. S: Benthic fluxes and the cycling of biogenic silica and carbon in two southern California borderland basins, Geochim. Cosmochim. Ac., 51, 1345-1363, 1987.
Buckley, D. E. and Hargrave, B. T.: Geochemical characteristics of surface sediments, in: Investigations of Marine Environmental Quality in Halifax Harbour, edited by: Nicholls, H. B., Can. Tech. Rep. Fish. Aqua. Sci., 1693, 9-36, 1989.

Burdige, D. J.: 5.09 Estuarine and coastal sediments - coupled biogeochemical cycling, in: Treatise on Estuarine and Coastal Science, Vol. 5, edited by: Wolanski, E. and McLusky, D. S., Academic Press, Waltham, 4, 279-308, 2011.

Burnett, W. C., Bokuniewicz, H., Huettel, M., Moore, W. S., and Taniguchi, M.: Groundwater and pore water inputs to the coastal zone, Biogeochemistry, 66, 3-33, 2003.

Charette, M. A., Gonneea., M. E., Morris., P. J., Statham, P., Fones, G., Planquette, H., Salter, I., and Garabato, A. N.: Radium isotopes as tracers of iron sources fueling a Southern Ocean phytoplankton bloom, Deep-Sea Res. Part II, 54, 1989-1998, 2007.

Chen, C.-T. A. and Wang, S.-L.: Carbon, alkalinity and nutrient budgets on the East China Sea continental shelf, J. Geophys. Res., 104, 20675-20686, 1999.

Colbert, S. L. and Hammond, D. E.: Shoreline and seafloor fluxes of water and short-lived Ra isotopes to surface water of San Pedro Bay, Mar. Chem., 108, 1-17, 2008.

Emerson, S., Jahnke, R., and Heggie, D.: Sediment-water exchange in shallow water estuarine sediments, J. Mar. Res., 42, 709-730, 1984.

Fader, G. B. J. and Miller, R. O.: Surficial geology, Halifax Harbour, Nova Scotia, Geol. Surv. Can. Bull., 590, 1-163, 2008.

Fennel, K., Wilkin, J., Levin., J., Moisan, J., O’Reilly, J. O., and Haidvogel, D.: Nitrogen cycling in the Middle Atlantic Bight: Results from a three-dimensional model and implications for the North Atlantic nitrogen budget, Global Biogeochem. Cy., 20, GB3007, doi:10.1029/2005GB002456, 2006.

Fennel, K., Brady, D., DiToro, D., Fulweiler, R. W., Gardner, W. S., Giblin, A., McCarthy, M. J., Rao, A., Seitzinger, S., ThouvenotKorppoo, and M., Tobias, C.: Modeling denitrification in aquatic sediments, Biogeochemistry, 93, 159-178, 2009.

Hancock, G. J., Webster, I. T., and Stieglitz, T. C.: Horizontal mixing of Great Barrier Reef waters: Offshore diffusivity determined from radium isotope distribution, J. Geophys. Res., 111, C12019, doi:10.1029/2006JC003608, 2006.

Hargrave, B. T.: Seasonal Changes in Oxygen Uptake by Settled Particulate Matter and Sediments in a Marine Bay, J. Fish. Res. Board Can., 35, 1621-1628, 1978.

Hargrave, B. T. and Taguchi, S.: Origin of Deposited Material Sedimented in a Marine Bay, J. Fish. Res. Board Can., 35, 16041613, 1978.

Hargrave, B. T., Phillips, G. A., and Taguchi, S.: Sedimentation Measurements in Bedford Basin, 1973-1974, Tech. Rep. Fish. Mar. Serv. Envir., 608, 1-129, 1976.

Hargrave, B. T., Peer, D. L., and Wiele, H. F.: Benthic biological observations, in: Investigations of Marine Environmental Quality in Halifax Harbour, edited by: Nicholls, H. B., Can. Tech. Rep. Fish. Aqua. Sci., 1693, 37-45, 1989.

Huettel, M. and Webster, I. T.: Porewater flow in permeable sediment, in: The Benthic Boundary Layer: Transport Processes and Biogeochemistry, edited by: Boudreau, B. P. and Jorgensen, B. B., Oxford University Press, New York, 144-179, 2001.

Jahnke, R. A. and Jahnke, D. B.: Rates of C, N, P and Si recycling and denitrification at the US Mid-Atlantic continental slope depocenter, Deep-Sea Res. Part I, 47, 1405-1428, 2000. 
Jahnke, R. A., Nelson, J. R., Marinelli, R. L., and Eckman, J. E.: Benthic flux of biogenic elements on the Southerwestern US continental shelf: influence of pore water advective transport and benthic microalgae, Cont. Shelf Res., 20, 109-127, 2000.

Jahnke, R., Richards, M., Nelson, J., Robertson, C., Rao, A., and Jahnke, D.: Organic matter remineralization and porewater exchange rates in permeable South Atlantic Bight continental shelf sediments, Cont. Shelf Res., 25, 1433-1452, 2005.

Johnson, K. M., Willis, K. D., Butler, D. B., Johnson, W. K., and Wong, C. S.: Coulometric total carbon dioxide analysis for marine studies: maximizing the performance of an automated gas extraction system and coulometric detector, Mar. Chem., 44, 167-188, 1993.

Kepkay, P. E, Niven, S. E. H., and Jellett, J. F.: Colloidal organic carbon and phytoplankton speciation during a coastal bloom, J. Plankton Res., 19, 369-389, 1997.

Lettmann, K. A., Riedinger, N., Ramlau, R., Knab, N., Böttcher, M. E., Khalili, A., Wolff, J.-O, and Jørgensen, B. B.: Estimation of biogeochemical rates from concentration profiles: a novel inverse method, Estuar. Coast. Shelf S., 100, 26-37, 2012.

Li, C. and Cai, W.-J.: On the calculation of eddy diffusivity in the shelf water from radium isotopes: High sensitivity to advection, J. Marine Syst., 86, 28-33, 2011.

Li, W. K. W. and Dickie, P. M.: Monitoring phytoplankton, bacterioplankton, and virioplankton in a coastal inlet (Bedford Basin) by flow cytometry, Cytometry, 44, 236-246, 2001.

Li, W. K. W. and Harrison, W. G.: Propogation of an atmospheric climate signal to phytoplankton in a small marine basin, Limnol. Oceanogr., 53, 1734-1745, 2008.

Men, W., Wang, F., and Liu, G.: ${ }^{224}$ Ra and its implications in the East China Sea, J. Radioanal Nucl. Ch., 288, 189-195, 2011.

Moore, W. S.: Radium 228 in the South Atlantic Bight, J. Geophys. Res., 92, 5177-5190, 1987.

Moore, W. S.: Determining coastal mixing rates using radium isotopes, Cont. Shelf Res., 20, 1993-2007, 2000.

Moore, W. S.: Sources and fluxes of submarine groundwater discharge delineated by radium isotopes, Biogeochemistry, 66, 7593, 2003.

Moore, W. S. and Arnold, R.: Measurement of ${ }^{223} \mathrm{Ra}$ and ${ }^{224} \mathrm{Ra}$ in coastal waters using a delayed coincidence counter, J. Geophys. Res., 101, 1321-1329, 1996.

Moore, W. S. and de Oliveira, J.: Determination of residence time and mixing processes of the Ubatuba, Brazil, inner shelf waters using natural Ra isotopes, Estuar. Coast. Shelf S., 76, 512-521, 2008

Moore, W. S., Beck, M., Riedel, T., Rutgers van der Loeff, M., Dellwig, O., Shaw, T. J., Schnetger, B., and Brumsack, H.-J.: Radium-based pore water fluxes of silica, alkalinity, manganese, DOC, and uranium: A decade of studies in the German Wadden Sea, Geochim. Cosmochim. Ac., 75, 6535-6555, 2011.

Platt, T.: Analysis of the importance of spatial and temporal heterogeneity in the estimation of annual production by phytoplankton in a small, enriched, marine basin, J. Exp. Mar. Biol. Ecol., 18, 99-109, 1975.

Platt T., Prakash, A., and Irwin, B.: Phytoplankton nutrients and flushing of inlets on the coast of Nova Scotia, Nat. Can., 99, 253261, 1972.
Punshon, S. and Moore, R. M.: Nitrous oxide production and consumption in a eutrophic coastal embayment, Mar. Chem., 15, 37 51,2004

Redfield, A. C., Ketchum, B. H., and Richards, F. A.: The influence of organisms on the composition of sea water, in: Comparative and Descriptive Oceanography, edited by: Hill, M. N., Wiley, New York, 26-77, 1963.

Riddle, A. M. and Lewis, R. E.: Dispersion Experiments in U.K. Coastal Waters, Estuar. Coast. Shelf S., 51, 243-254, 2000.

Robinson, C. and Williams, P. J. 1. B.: Respiration and its measurement in surface marine waters, in: Respiration in Aquatic Ecosystems, edited by: del Giorgio, P. A. and Williams, P. J. 1. B., Oxford University Press, Oxford, 147-180, 2005.

Rudnick, D. T. and Oviatt, A.: Seasonal lags between organic carbon deposition and mineralization in marine sediments, J. Mar Res., 44, 815-837, 1986.

Sarmiento, J. L., Feely, H. W., Moore, W. S., and Broecker, W. S.: The relationship between vertical eddy diffusion and buoyancy gradient in the deep sea, Earth Planet. Sci. Lett., 32, 357-370, 1976.

Shadwick, E. H., Thomas, H., Azetsu-Scott, K., Greenan, B. J. W., Head, E., and Horne, E.: Seasonal variability of dissolved inorganic carbon and surface water $\mathrm{pCO}_{2}$ in the Scotian Shelf region of the Northwestern Atlantic, Mar. Chem., 124, 23-37, 2011.

Shan, S. and Sheng, J.: Examination of circulation, flushing time, and dispersion in Halifax Harbour of Nova Scotia, Canada, Water Qual. Res. J. Can., in press, 2013.

Shan, S., Sheng, J., and Thompson, K. F.: Simulating the threedimensional circulation and hydrography of Halifax Harbour using a multi-nested coastal ocean circulation model, Ocean Dynam., 61, 951-976, 2011.

Simmons Jr., G. M.: Importance of submarine groundwater discharge (SGWD) and seawater cycling to material flux across sediment/water interfaces in marine environments, Mar. Ecol.-Prog. Ser., 84, 173-184, 1992.

Ståhl, H., Tengberg, A., Brunnegård, J., Byørnbom, E., Forbes, T. L., Josefson, A. B., Kaberi, H. G., Karle Hassellöv, I. M., Olsgard, F., Roos, P., and Hall, P. O. J.: Factors influencing organic carbon recycling and buriel in Skagerrak sediments, J. Mar. Res., 62, 867-907, 2004.

Sun, Y. and Torgersen, T.: Rapid and precise measurement method for adsorbed ${ }^{224} \mathrm{Ra}$ on sediments, Mar. Chem., 61, 163-171, 1998.

Syvitski, J. P. M., Asprey, K. W., and LeBlanc, K. W. G.: In-situ characteristics of particles settling within a deep-water estuary, Deep-Sea Res. Part II, 42, 223-256, 1995.

Thomas, H., Schiettecatte, L.-S., Suykens, K., Koné, Y. J. M., Shadwick, E. H., Prowe, A. E. F., Bozec, Y., de Baar, H. J. W., and Borges, A. V.: Enhanced ocean carbon storage from anaerobic alkalinity generation in coastal sediments, Biogeosciences, 6, 267274, doi:10.5194/bg-6-267-2009, 2009.

Thomas, H., Craig, S. E., Greenan, B. J. W., Burt, W., Herndl, G. J., Higginson, S., Salt, L., Shadwick, E. H., and Urrego-Blanco, J.: Direct observations of diel biological $\mathrm{CO}_{2}$ fixation on the Scotian Shelf, northwestern Atlantic Ocean, Biogeosciences, 9, 23012309, doi:10.5194/bg-9-2301-2012, 2012. 